\title{
THE ASCENSION IN LUKE-ACTS
}

By John F. Maile

'Theologically and empirically the Ascension of Jesus Christ is at the very heart of the New Testament. ' 1 If those words, with which Brian Donne closes his recent study of the significance of the ascension of Jesus in the NT, are true of the NT as a whole, an even stronger statement could be made in respect of the ascension in Luke-Acts. If we may assume for one moment that Luke 24:50-53 and Acts 1:9-11 are descriptions of the same incident, Luke has chosen to present the ascension twice, as the culmination and climax of his gospel and as the most striking element in the introduction to his second volume. ${ }^{2}$ That in so doing he provides the only description in the NT of a visible ascension of Jesus imparts to these two short narratives an importance out of all proportion to their length; and by using these ascension accounts to form the link between his two volumes Luke would seem to indicate their significance for a proper understanding of his theology and purpose. When one considers the crucial nature of this event for Luke it is perhaps surprising to note the relative brevity with which many commentators deal with these sections of Luke and Acts. ${ }^{3}$ Equally noteworthy is the

1. B. K. Donne, Christ Ascended (Exeter: Paternoster, 1983) 67.

2. 'Luke described the event twice because he put such great weight upon it' (E. Franklin, Christ the Lord. A study in the Purpose and Theology of Luke-Acts [London: SPCK, 1975] 35). As is virtually undisputed, it is assumed here that the same author was responsible for Luke and Acts. Cf. W. G. Kümmel, Introduction to the New Testament (London: SCM, 1975 ${ }^{2}$ ), 147-150, 156-185; but see also A. W. Argyle, 'The Greek of Luke and Acts', NTS 20 (1973-4) 441-445.

3. This is more applicable to commentators on Luke than on Acts; but it applies also to more general introductions to Luke's writings. For example, D. Juel, in an otherwise helpful and informative book (LukeActs [London: SCM, 1984]), makes almost no mention of the ascension. 
scarcity of major works devoted to the ascension in general and its place in Luke-Acts in particular. While there has been a reasonable flow of articles and short studies, the last fifty years has seen only two major investigations: V. Larranaga's admittedly exhaustive treatment, and that of G. Lohfink, which, whatever one's response to some of his conclusions, must be considered the definitive modern study of the ascension in the NT, and in Luke-Acts especially. ${ }^{4}$ To neglect Luke's ascension accounts is almost certainly to run the risk of missing some of his most important emphases. It is not possible here, of course, to attempt anything like an exhaustive study; attention will be focussed on three issues in particular which could be expressed by means of the three interrogatives, what? when? and why? That is, what is Luke actually describing in his ascension narratives; how are the 'forty days' of Acts 1:3 to be understood; and what significance does luke attach to the ascension event?

Some Preliminary Considerations

Any study of these passages in Luke-Acts is immediately confronted with two problems - that of determining the correct text of the closing verses of the gospel and the opening verses of Acts; and the extent to which, if at all, these same verses are the result of post-Lukan interpolations. These are not unimportant

4. V. Larranaga, L'Ascension de Notre-Seigneur dans le Nouveau Testament (Rome: Pontifical Biblical

Institute, 1938); G. Lohfink, Die Himmelfahrt Jesu (Munich: Kosel, 1971). Lohfink's book contains a very full bibliography, which can be supplemented by $F$. Bovon, Luc le Theologien (Neuchâtel: Delachaux \& Niestlé, 1978) 119-129. In addition to Donne's book (see note 1 ) the following should be noted: W. H. Marrevee, The Ascension of Christ in the Works of st. Augustine (Ottawa: University of Ottawa Press, 1967); P. Toon, The Ascension of our Lord (New York: Nelson, 1984); R. F. O'Toole, 'Luke's Understanding of Jesus' Resurrection-Ascension-Exaltation', BTB 8 (1978) 106-114; and $\mathrm{W}$. Baird, 'Ascension and Resurrection: an Intersection of Luke and Paul,' in W. E. March (ed.), Texts and Testaments: Critical Essays on the Bible and Early Church Fathers (San Antonio: Trinity University, 1980) 3-18. 
issues as they affect considerably the judgements to be made in all of the areas which form the subject of this paper, and they must; therefore, be discussed, albeit only in summary form.

(i) As far as the text is concerned, the omission

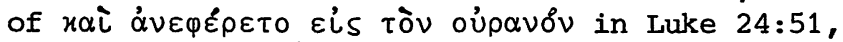

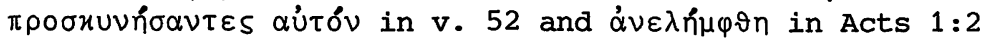
on the grounds that they are 'western non-interpolations' (perhaps introduced when Luke and Acts were separated in the canon) significantly assists the argument that Luke 24 does not relate the ascension as in Acts $1: 9-11,5$ can be used to support the interpretation of luke 24 as an invisible ascension, ${ }^{6}$ and adds considerable weight to the contention that the ascension account in Acts 1:9-11 is the culmination of a gradual development, beginning with the invisible exaltation of the earliest kerygua and ending (as far as the NT is concerned) with the visible phenomenon of Acts $1 .{ }^{7}$ However, in all three instances the disputed words should almost certainly be retained: the textual evidence for omission is weak, the use of the unusual $\alpha$ $v \propto \varepsilon \hat{\varepsilon} \omega$ in Luke 24:51 is unlikely by a later redactor at a time when $\alpha \nu \alpha \lambda \alpha \mu \beta \alpha \dot{\alpha} \nu \omega$ was the more or less accepted term for the ascension, Mark 16:18-19 can probably be adduced as evidence for the longer readings in Luke 24, and the omissions are probably to be attributed either to a harmonising tendency on the part of an editor wishing to remove the apparent contradiction between an Easter Day ascension in Luke 24 and the forty-day interval in Acts 1, or possibly to a desire to exclude such specific descriptions of the ascension on the part of an editor opposed to any idea of bodily resurrection. 8

5. For example, W. Michaelis, 'Zur Ueberlieferung der Himmelfahrtsgeschichte', Th BI 4 (1925) 101-109; E. E. Ellis, The Gospel of Luke (London: Oliphants, 1974) 280.

6. A. von Harnack, Die Apostelgeschichte (Leipzig: Hinrichs, 1908) 128.

7. For a brief summary of such developmental theories see P. Benoit, 'The Ascension' in Jesus and the Gospel. 1 (London: Darton, Longman \& Todd, 1973) 222-226.

8. Larranaga ( $L^{\prime}$ Ascension 145-211) has a very full discussion of this problem. Also see Benoit, 'Ascension' 238-240; B. M. Metzger, A Textual Commentary on the Greek New Testament (London: UBS, 1971) 273-277. 
(ii) There is no shortage of suggestions regarding the interpolation of material into the ascension accounts. ${ }^{9}$ While not in itself requiring a theory of wholesale interpolation, the so-called $\mu$ év solitarium of Acts 1:1 does present a problem in that, according to normal Greek usage, and particularly in the context of such a prologue as this, there should be a corresponding $\delta \varepsilon$ which introduces a review of the contents of the book. The absence of this $\delta \varepsilon$ clause has led to the suggestion that the original has been suppressed in favour of the present text, either to enable new traditions to be included or simply to replace a text which, for whatever reason, the later editor found unsatisfactory. Verses 1 and 2 may still be Lukan but, on this view, vv. 3-5 are a later interpolation. 10 There are, however, notable examples of books which begin with a summary of a preceding volume but which do not proceed to a preview of what is to come, ${ }^{11}$ and there are occasions when $\mu \varepsilon v$ may be found on its own for the purpose of emphasising that which it introduces. ${ }^{12} \mathrm{H}$. Conzelmann's suggestion that the omission of the $\delta \varepsilon$ is simply the result of negligence is unlikely in respect of luke of all NT writers, but $\mathrm{K}$. Lake's comment is more to the point when he observes that the absence of such a $\delta \dot{\varepsilon}$ clause would be

9. For a convenient summary see Lohfink, Himmelfahrt 25-27.

10. For literature see Lohfink, Himmelfahrt 25-26. Of special interest is P. Menoud who espoused this view in 'Remarques sur les textes de l'ascension dans LucActes', Neutestamentliche studien für Rudolf Bultmann zu seinem siebzigsten Geburtstag, W. Eltester (ed.) (Berlin: Töpelmann, 1954) 148-156, but later witharew it in 'Pendant Quarante Jours', Neotestamentica et Patristica, W. C. van Unnik (ed.) (Leiden: Brill, 1962) 148-156.

11. For example, Josephus, Antiquities, Books 8 and 13; cited by D. Fuller, Easter Faith and History (London: Tyndale, 1968) 197, and H. Conzelmann, Die Apostelgeschichte (Tübingen: Mohr, 1963) 21.

12. B. Reicke, 'Zum Sprachlichen Verständnis von Kol. 2:23', Theologica Studia 6 (1953) 43. 
so offensive to anyone conversant with classical Greek that had there been an original $\delta \varepsilon$ clause no editor would have cut it out, and were it missing it would be the first thing an editor would include. ${ }^{3}$ Furthermore, while a $\delta \varepsilon$ clause may be missing, Acts $1: 1-2$ contain by implication a description of the contents of this volume, in the sense of a continuation of the work begun by Jesus, and in v. 8 this is explicitly stated in terms of the church's mission.

More wide-ranging interpolation hypotheses have been suggested, however, which regard both Luke 24:50-53 and Acts $1: 1-5$ as later insertions, perhaps included to smooth over the break when the originally one-volume work was divided into the two volumes that we know as Iuke and Acts. Evidence for such editorial work is found in what is considered to be the clumsiness of these verses, which. is so alien to Luke's usual style; the awkwardness of the three references to the ascension; the likelihood that Acts 1:6 originally followed on from Luke 24:49; and the contradiction presented by the forty days in Acts $1: 3$.

But such 'evidence' is not strong enough to support an interpolation theory. It is at least surprising that the supposed splitting of Luke's originally single volume has left no traces in terms of MS evidence or external testimony. The very awkwardness of these verses tells against later redaction rather than for it, for 'it is harder to conceive of these difficulties as arising from a redactor, whose aim is to smooth things up, than from Luke himself'. ${ }^{14}$ It was for this reason that P. Menoud, who originally espoused the theory of redactional interpolation, withdrew it on the grounds that, although there are linguistic peculiarities in these verses which are astonishing coming from Luke's pen, the paragraph is too short and the language of luke

13. Conzelmann, Apostelgeschichte 21; K. Lake, 'The Preface to Acts and the Composition of Acts', in $\mathrm{K}$. Lake and F. J. Foakes-Jackson, The Beginnings of Christianity, Vol. 5 (London: Macmillan, 1933), 4-5.

14. Fuller, Easter Faith 196; cf. Franklin, Christ the Lord 37. 
too irregular, to enable stylistic observations to prevail against the theological coherence of the unit formed by Luke 24 and Acts $1 .^{15}$ Such linguistic analysis as is possible in a short section like luke 24:50-53 shows that 'the diction of this short narrative is distinctively Lukan', as V. Taylor has demonstrated. ${ }^{16}$ The suggestion concerning the original connection between Luke 24:49 and Acts 1:6 must contend with the observation made by $W$. G. Kümmel, that if the latter verse originally followed on from the former, it involves the disciples returning to a building which they have never left! ${ }^{17}$ Moreover, the Acts passage is intelligible as it now stands, with vv. 6-8 possibly acting as a counter to the apparently Jewish tendency and outlook of the disciples, a tendency perhaps encouraged by the command to stay in Jerusalem in $v .5 .^{18}$ As regards the awkwardness of the three references to the ascension, and apparent contradictions between the two accounts, notably the forty days, these will be dealt with in the course of this paper. Suffice it to say at this point that if luke were responsible for the two-volume format there is nothing inherently surprising in a brief description of the ascension at the end of his first volume, a necessary reference to it in the summary of that first volume at the commencement of the second, and then a fuller description of it as the starting point of that second volume. Such a procedure could have been forced upon luke by the practical considerations of the length of the scrolls available to him which necessitated a swift conclusion to the Gospel; but it is more probable that the differences between the accounts are due to his theological motivation which has consciously led to the schematic grouping of material in luke 24 , so that episodes and conversations which were in reality separated in time have been narrated as if they all

15. See note 10 for the details of Menoud's work.

16. The Passion Narrative of St. Luke (Cambridge: CUP, 1972) 114-115.

17. 'Das Urchristentum', Th R, n.f. 22 (1954) 195-196.

18. Benoit, 'Ascension! 217-218, following U. Holzmeister, 'Der Tag des Himmelfahrt des Herrn', ZKTh 55 (1931) 44-82, especially 58-59. 
belonged together on the same day, in the sure knowledge that any misunderstanding to which this might give rise (e.g. with regard to chronology) could and would be resolved in Acts which, again for theological reasons, would present a quite distinctive account. The difficulties raised in this connection, real as they are, and such as deserve more detailed discussion than that provided here, are nevertheless not sufficient to require a theory of redactional interpolation to explain them. Luke 24:50-53 and Acts 1 may be confidently accepted as coming from the pen of Luke, and these verses, therefore, retain their crucial significance for the understanding both of the ascension and of Lukan theology.

\section{WHAT IS THE 'ASCENSION' IN LUKE-ACTS?}

It is the very uniqueness of Luke's ascension accounts within the NT which gives rise to this question and to the variety of answers that have been presented. While the NT speaks both separately, and also in a variety of different combinations, of four events in the experience of the post-Calvary Jesus, namely, resurrection, exaltation, ascension and session at God's right hand, the overwhelming majority of references (if not in fact the unanimous testimony) seem to make it clear that while these things may be separated in thought, they in fact refer to four elements which in reality are inseparable, and together they describe the glorification of Christ, so that for every strand of NT thought the risen Christ is the exalted and ascended Lord at the Father's right hand. There would appear to be no indisputable reference outside Luke-Acts to a visible ascension before witnesses. I9 How then are Luke's apparently unique narratives to be understood, and what relation do they have to the rest of the NT and its understanding of resurrection and exaltation?

19. This is the conclusion reached by Lohfink after a lengthy analysis of all the relevant NT passages (Himmelfahrt 81-98). It is certainly possible to query Lohfink's exegesis of some of these texts (cf. Bovon, Luc 184) but the overall conclusion should be accepted. 
It is not the purpose of this paper to examine in detail all the various interpretations which have been offered. They can be briefly classified as follows.

(i) Interpretations which regard the accounts as wholly or largely 'legendary'. Often Luke's narratives are seen as the culmination of a process involving the materialisation of the resurrection appearances in which, as the risen Lord was presented in more and more concrete terms it became increasingly necessary to provide an equally concrete mode of departure for him. 20 Particularly with Luke-Acts in mind, a similar developmental theory was advanced by A. Harnack who thought in terms of the gradual evolution of understanding based on the earliest exaltation kerygma. At the outset resurrection and ascension/exaltation were identified, the latter being a matter of faith alone, since it was by nature an invisible event; gradually resurrection and ascension were separated, although ascension still took place on Easter Day and remained an invisible event (as in luke 24 according to Harnack's understanding); finally the separation lengthened into an interim period of forty days climaxing in a visible ascension as reported in Acts 1.21 While there are numerous variations within this approach they all rely on the idea of a process of change or development, which in fact is their Achilles' heel, for it presupposes the wholly untenable notion that the earliest exaltation kerygma centred upon a wholly 'spiritual', non-corporeal resurrection and exaltation, of which there is little likelihood in a faith rooted in Judaism and for which there is no evidence in the NT. Furthermore, it must be asked why there is no trace elsewhere in the NT of this ascension 'legend', especially in writings which are later than Luke-Acts. Supporters of these views are obliged either to push the date of Iuke-Acts well into the second century, or to appeal to the theory of a later interpolation, which was shown above to be unlikely.

20. Lohfink briefly surveys this approach and lists various exponents of it (Himmelfahrt 19); see also Benoit, 'Ascension' 222-226.

21. A lengthy discussion of Harnack's position is found in Larranaga, L'Ascension 64-74; see also Lohfink, Himmelfahrt 19-22. 
(ii) Since there appears to be little or no evidence in the NT for the sort of developing tradition which might explain the presence of the ascension narratives in Luke, and since both Luke 24 and Acts 1 contain numerous distinctly Lukan traits, could it be that both narratives should be attributed solely to Luke who, along with the other Gospel writers, must be recognised as an author and a theologian and not merely a scissorsand-paste editor who hands on the tradition? ${ }^{22}$ That Luke writes as a theologian can hardly be denied, but that redaction does not have to imply invention must be equally stressed. For the most part it is possible to observe the way in which Luke has taken over and shaped the traditions which came to him (at least in respect of the Gospel), and where, because there is no parallel material in the other Gospels this is not possible or at least is not so straightforward, it should not be too readily assumed that luke has no tradition upon which to work. Matthew 28:16-20, while admittedly not containing the ascension theme, nor even a withdrawal of Jesus, nevertheless provides some points of contact with Luke's ascension accounts (the Eleven, the mountain, worship, the Lordship of Jesus - announced in Matthew, depicted by the cloud in Acts - and possibly even the theme of the presence of Jesus with his people); John 20 can be claimed to point to knowledge of some sort of ascension tradition; and 1 Corinthians 15:8 may well imply a tradition of the ending of the resurrection appearances. Luke has undoubtedly shaped the ascension narratives in his own way to present his own theological emphases, but this need not mean that he had no traditional material at

22. The extent of Lukan redaction, not only in respect of the ascension, but in Luke and Acts as a whole, has been forcefully emphasised by both H. Conzelmann, The Theology of Saint Luke (London: Faber, 1960) and E. Haenchen, The Acts of the Apostles (Oxford: Blackwell, 1971). Cf. also S. G. Wilson, 'The Ascension: a Critique and an Interpretation' $Z N W 59$ (1968) 269-281; and Lohfink (Himmelfahrt) where one of his main conclusions is that both ascension accounts stem from Luke alone. 
all from which to work, nor that there is no historical basis to his narratives. 23

(iii) If there is a traditional basis for Luke's accounts, how are they to be understood in relation to the identification of resurrection and exaltation in the rest of the NT? This question has also received a variety of answers from those wishing to take seriously the Lukan narratives. For some, Luke, in common with the NT generally, depicts an Easter Day ascension but which is presented as being before witnesses. The account in Acts is deliberately different, incorporating as it does the forty days, which for Luke is a formal contradiction only, enabling him to make full use of the typological possibilities presented by this number. ${ }^{24}$ For others, Luke describes in both Luke 24 and Acts 1 precisely that which the rest of the NT refers to whenever it speaks of ascension or exaltation, with the result that the risen Jesus can be considered to have been glorified at the resurrection but not exalted to the right hand of God until the ascension on the fortieth day. ${ }^{25}$ In almost total contrast to this is the view which regards the Lukan accounts as having little or nothing to do with ascension/exaltation as such, in that for Luke the risen Jesus is already the ascended and exalted Lord, who appears from heaven during the forty days, and whose final departure at the end of the period of the appearances is depicted in luke 24 and Acts 1. For some exponents of this view Luke 24 and Acts 1 relate the same final departure, for others luke 24 is a parting, Acts 1 the final parting. ${ }^{26}$ It will become clear as we proceed to an examination of Luke's narratives that each of these approaches has a contribution to make without being fully persuasive as they now stand.

23. For the possibility of an ascension tradition upon which luke could have built, note the comments by Bovon (LuC 184-185), and for a suggestion as to how Luke may have built his ascension accounts, see G. R. Osborne, The Resurrection Narratives (Grand Rapids: Baker, 1984) 266-270.

24. J. G. Davies, He Ascended into Heaven (London: Lutterworth, 1958).

25. Larranaga, L'Ascension 629-637; J. N. Geldenhuys, Commentary on the Gospel of Luke (London: Marshall, Morgan \& Scott, 1950) 645. Franklin (Christ 30) observes that '...the ascension... is understood as the actual moment of the glorification of Jesus.' For Franklin, however, this is theologically rather than historically determined for Luke.

26. Michaelis, 'Ueberlieferung' 101-109; Benoit, 'Ascension'

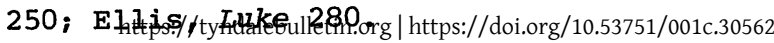




\section{Luke 24 and Acts 1.}

Reference has frequently been made to Luke's ascension narratives, which assumes that Luke 24 and Acts 1 are in fact relating the same event. Although this has not gone unchallenged there seems little doubt that this is the case. The occurrence of $\alpha \nu \varepsilon \lambda \hat{n} \mu \varphi \vartheta \eta$ in Acts 1:2, referring to material contained in the previous volume, makes it clear that the Gospel contains an account of the ascension, and this can only be Luke 24:50-53 (cf. $\alpha \dot{\alpha} \lambda n_{\mu \varphi \vartheta \eta}$ in 1:22). Furthermore, while there are obvious differences between the two accounts the similarities are such as to make identity a virtual certainty. Both passages refer to the Eleven, to world mission as the necessary prerequisite to the coming of the Kingdom, to the need to stay in Jerusalem and await the coming of the Spirit, to the role of the disciples as witnesses, to Jesus being received up into heaven, to the same geographical location (Bethany/Mount of Olives), to the return to Jerusalem, and to attendance at the temple and prayer. Not only is the subject matter clearly the same, there are numerous linguistic parallels which underline the identical nature of the incidents recorded. ${ }^{27}$ This conclusion is important because it means that both narratives can and must be taken into account in determining the nature of the event described, and since the similarities serve only to highlight the differences, these must be adequately explained.

In what follows it will be argued that in both Luke 24 and Acts 1 Luke describes the ending of the resurrection appearances in the final departure of the visible presence of the already exalted Lord. In essence this is a position not markedly different from that adopted by $W$. Michaelis and $P$. Benoit, but it is perhaps not unfair to say that both of these writers have rightly pointed out weaknesses in some of the alternative interpretations and have shown the possibility of their own position without in fact demonstrating from the lukan writings themselves that this possibility is in fact to be preferred. Certainly many scholars remain unconvinced. Lohfink, for example, while acknowledging the value of their work, is far from convinced that the two Lukan accounts reflect a departure tradition, especially as such

27. B. W. Bacon, 'The Ascension in Luke and Acts', Expositor 7 (1909) 256-257; Davies, He Ascended 42, 187. 
a tradition cannot be demonstrated from elsewhere in the $\mathrm{NT}{ }^{28}$ and E. Franklin, who argues that for Luke the ascension was the moment of glorification (or the event which immediately preceded the invisible exaltation which took place in heaven) and that Luke's resurrection appearances are devoid of any hint of a glorification already accomplished, feels that the view being presented here 'underplays the significance of the cloud in Acts $1.1^{29}$ It would be presumptuous to believe that any arguments presented here might tip the scales decisively in favour of the proposed interpretation, but there are three considerations which may add a little weight. They concern the 'form' of the story, the significance of the resurrection for Luke's Christology, and the presentation of the exaltation of Christ by Luke outside the ascension narratives.

\section{The 'form' of the Lukan narratives}

It is one of the merits of Lohfink's study that he acknowledges the importance of seeking to identify the 'form' of the Lukan accounts, and that he provides such a lucid and full survey of ascension 'forms' in both Hellenism and Judaism. ${ }^{30}$ In Greco-Roman antiquity two forms of ascension story can be distinguished: the socalled journey of the soul to heaven, and what can be called the 'rapture' story. For the latter certain verbs

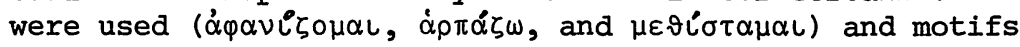
such as a mountain, a funeral-pile, light, darkness, wind, cloud, and heavenly confirmation frequently occur. Many of these motifs are found also in the old Testament and Judaism where, however, it is necessary to distinguish between at least four types of story: a journey to heaven to receive revelation and a subsequent return to earth; ${ }^{31}$ the taking up of the soul after death; ${ }^{32}$ the rapture of a living person, who is taken up to heaven never to return (e.g., Enoch, Elijah, Esdras and Baruch) $;^{33}$ and the ascension at the end of an

28. Himmelfahrt 18-19.

29. Christ 30-41.

30. Himmelfahrt 32-79.

31. Test. Abraham 7:19 - 8:3. See Lohfink, Himmelfahrt 51-53 for further examples.

32. Test. Abraham 14:6-7; further examples, Lohfink, Himmelfahrt 54 .

33. Gn. 5:24; Slavonic Enoch 67 (which Lohfink considers the most important parallel to luke's accounts); $2 \mathrm{Ki}$. 2:1-18 (Himmelfahrt 55-70). 
appearance. ${ }^{34}$ Lohfink concludes his extremely detailed investigation of these 'forms' by placing the Lukan accounts firmly within the 'rapture' category, on the grounds that numerous rapture motifs are found in Luke's narratives (the mountain, Acts $1: 12$; the final conversation with the disciples, Acts 1:6-8; the cloud which takes Jesus up, Acts 1:9; the worship offered by the disciples, Lk. 24:52; the heavenly confirmation by the angels, Acts 1:11; and the worship of God, Lk. 24:53), that Luke uses the most important old Testament word for a rapture ('́) $\left.\alpha \lambda \alpha \mu \beta \alpha^{\prime} \nu o \mu \alpha \iota\right), 35$ that most early church writers as a matter of course conceive of the ascension in terms of a rapture, and, most importantly for Lohfink, the ascension is related by Luke from the standpoint of the observers, from an earthly perspective, which belongs to the fundamental scheme of a rapture. ${ }^{36}$

Lohfink admits, however, that there is no one rapture story, in the Greco-Roman literature or that of the $O T$ and Judaism, upon which Luke is dependent. ${ }^{37}$ He also acknowledges the possibility, without attributing great significance to it, of the influence of another 'form', namely, the ascension at the end of an appearance. Indeed he concedes that the emphasis on the reaction of the disciples in luke 24:52-53, and on their role as witnesses in Acts 1, in fact the relating of the story from the disciples' viewpoint, is as much a feature of this 'form' as of the rapture accounts. When it is further noted that to a considerable extent not only in the ascension narratives but also in Luke 24 and Acts 1 as a whole attention is focussed upon the disciples and their preparation for the future, and that indeed the theme of preparing the disciples is prominent throughout

34. Lohfink (Himmelfahrt 70-72) gives the examples, the most significant of which is usually held to be Tob. 12:20-22.

35. It is not strictly speaking true, however, as Lohfink claims (Himmelfahrt 76) that both Lukan accounts employ this verb. It is absent from Lk. 24:50-53.

36. Himmelfahrt 74-79.

37. In this he is undoubtedly correct. While there are some similarities between the Lukan accounts and, for example, $2 \mathrm{Ki}$. 2:1-18 and sirach 50:50-52, it is a mistake to suggest that such passages have had a decisive and formative effect on the way in which Luke has written his accounts. 
the whole of Luke's Gospel, ${ }^{38}$ the significance of this particular element in the determination of the 'form' of the story is greatly reduced. Again, although both accounts relate the same event this does not necessarily mean that both are in precisely the same 'form', and therefore to combine them when compiling a list of features found in a rapture story may be misleading. Lohfink's list of six features appears reasonably impressive, until one notes that four of the features belong to Acts 1 and two to Luke 24. Looked at individually, therefore, neither account is so impressively 'rapture'-like, especially Luke 24. In fact, the reaction of the disciples in Luke 24:52-53, coming as it does at the conclusion of an appearance, makes it at least as likely that luke was thinking in terms of an ascension at the end of an appearance, at least in the Gospel account. To deny this possibility, as Lohfink does, on the grounds that these verses do not only end an appearance but conclude the whole life of Jesus, is unconvincing. ${ }^{39}$ Luke does use $\dot{\alpha} \nu \alpha \lambda \alpha \mu \beta \alpha ́ v o \mu \alpha \iota$ three times in Acts 1, but the fact is that he uses

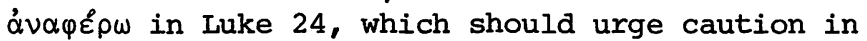
drawing too certain conclusions from his choice of verbs. There are elements in both Luke 24 and Acts 1 which are also found in both rapture stories and ascensions at the end of an appearance. This, however, does not exhaust the possibilities. Reference is frequently made to Sirach 50:50-52 in which there are undoubtedly linguistic parallels to Luke 24:50-53 - the lifting up of the hands, the use of $\pi \rho \circ \sigma x u \nu \varepsilon$ w and the repeated use of $\varepsilon \dot{\lambda} \lambda \circ \gamma^{\varepsilon} \omega$. While it is true that luke does not usually picture Jesus as a priest, it is hard to ignore this possibility in this passage. ${ }^{40}$ If we leave aside such priestly associations the ending of luke also recalls many of the parting scenes depicted in the OT. These scenes have been scrutinized by J. Munck who lists their main features as (i) a farewell speech prior to

38. See P. S. Minear, To Heal and to Reveal (New York: Seabury, 1976).

39. Himmelfahrt 75.

40. Cf. P. A. van Stempvoort, 'The Interpretation of the Ascension in Luke and Acts', NTS 5 (1958-9) 34-37. 
exaltation or death; (ii) a warning as to the consequences of obeying or disobeying the teaching; (iii) less often, an account of a life, drawing out its lessons; (iv) prophecy regarding the future; and (v) a meal sometimes precedes the final discourse (something which attains greater significance if Acts 1:4 refers to Jesus eating with the disciples). ${ }^{41}$ M.-J. Lagrange draws attention to Genesis 48:14-15, where the aged Jacob blesses his descendants at the close of his life, and in view of the use made by Iuke of Moses typology (see Stephen's speech in Acts 7) Moses' farewell address and blessing of the people in Deuteronomy 31-34 may also be relevant. ${ }^{42} \mathrm{H}$. Flender comments, 'The story in the Gospel is in the first place a farewell scene...'. ${ }^{43}$

What is to be made of all this? There appear to be elements of more than one 'form' present in Luke's ascension accounts which suggests that luke did not feel himself tied by any one 'form', and thus to seek to press his narratives into one such straight-jacket is to do him a disservice. There is a sense in which Luke is seeking to present a unique occurrence, which calls for a combination of elements to be used. We should not deny the rapture elements, which serve to confirm the exaltation rather than describe the event (see below), but due emphasis must be placed on the ideas relating to farewell blessing and departure, especially when it is recalled that luke, in contrast to the rest of the NT, is regularly at pains in his appearance stories to note the disappearance of whoever has appeared. ${ }^{44}$ Since both Luke 24:50-53 and Acts 1:9-11 come as the climax of appearances of the risen Jesus, it is not unreasonable to suggest that it is as such that they are primarily intended. That far more detail is given of this disappearance compared with others in Luke-Acts marks out this departure as different from all others, in that it is final. If on other grounds it can be shown that for Luke the risen Jesus is already exalted, then the rapture

41. 'Discours d'adieu dans le Nouveau Testament et dans la littérature biblique' in Aux sources de la tradition chrétienne: mélanges offerts à M. Maurice Goguel (Neuchâtel: Delachaux \& Niestlé, 1950) 155-170.

42. L'Évangile selon Saint Luc (Paris: Gabalda, 1948) 616.

43. St. Luke: Theologian of Redemptive History (London: SPCK, 1967) 11 .

44. Cf. Lk. $1: 38 ; 2: 15 ; 9: 33 ; 24: 31$; Acts $10: 7 ; 12: 10$. 
elements combine with the end of an appearance motif to present the final departure of the already exalted Lord. ${ }^{45}$ It is at this point, of course, that the 'form' becomes the servant of the theology, and to this we shall return later.

\section{The Resurrection and Luke's Christology}

It is sometimes claimed on the basis of the use of Christological titles in Luke and Acts that Luke's Gospel is full of Christological anachronisms, his 'promiscuous use of the titles' being due to 'his tendency to use the normal terminology of the Church'. 46 'For Luke Jesus is already on earth Christ, Son and Lord', says Conzelmann; 'in the use of the titles he makes no distinction between the historical figure and the Exalted Lord'.47 However, while it is true, in C. F. D. Moule's words, that 'Acts evinces an unshaken awareness that the exalted Lord is identical with Jesus, the man from Nazareth', 48 that there is no distinction at all for Luke between the earthly Jesus and the exalted Christ, and that the Jesus of the ministry is painted in colours rightly belonging only to the faith of the church, is not borne out by a careful examination of the facts.

Moule seeks to show that while Luke makes extensive use of the word xúplos with reference to Jesus, its use prior to the resurrection on the lips of men is, with rare exceptions, confined to those occasions when Luke as the narrator is referring to Jesus. The absence of this title on the lips of men during the ministry becomes all the more striking when it is observed that immediately the

45. Here we concur with R. J. Dillon, From Eye-Witnesses to Ministers of the Word (Rome: Pontifical Biblical Institute, 1978) 177 n.58: 'The point is that the Lucan narratives have incorporated the terms, motifs, and format of the old assumption stories for illustrative purposes, but not necessarily to fit the mystery of Easter into the assumption category.'

46. Conzelmann, Theology 171 n.1.

47. Ibid. 176.

48. 'The Christology of Acts' in I. E. Keck and J. I. Martyn (ed.) Studies in Luke-Acts (London: SPCK, 1968) 159-185; the quotation is from 165. 
narrative enters the post-resurrection period, in both the Gospel and Acts, the situation is entirely different. 'In Luke 24:34 and from the beginning of Acts onwards, the disciples are represented as doing precisely what they do not do in the Gospel before the resurrection: they freely apply the term xúplos to Jesus. 149 In spite of the large number of occurrences involved it might be possible to see here only a remarkable coincidence rather than a careful design on Luke's part (or indeed to use this evidence quite differently) were it not for a number of other factors which point in the same direction. 50 xúplos is not the only title to indicate a carefully maintained distinction. A subtle but precise differentiation is made by Luke between the assessment made by men during the ministry - that Jesus was one of the prophets - and the claim of the post-resurrection church that Jesus was the Prophet like Moses. In similar vein, the reference to the Son of Man in Acts 7:56 is in contrast to all other references to the Son of Man in glory, in that, whereas in the Gospels all such references are future, here in Acts the Son of Man is now in glory. Again, the designation 'Saviour' is significantly different in its application in the Gospel and in Acts; and the same can be said of the term viós. 'The common factor behind the contrasts that have been described is, of course, the consciousness of the resurrection as marking a decisive vindication of Jesus. 51

The resurrection is, therefore, the Christological watershed of Luke-Acts, for it is the resurrection which has made Jesus Lord, and in this regard Lukan theology is at one with the rest of the NT. This is borne out by Acts 2:32-36 which shows that when God raised the Jesus who had been crucified, this included as an integral part of that act his being exalted to the right hand of God and his reception of the spirit. This understanding is

49. Moule, 'Christology' 161.

50. Franklin (Christ 30ff.) is not impressed by Moule's thesis, but he does not seem to take the further material into account. He also appears to argue from an already established position regarding the resurrection and exaltation which compels a rejection of Moule's argument, but which is itself mistaken.

51. Moule, 'Christology' 165. 
indicated by the reference to David in v. 34. Peter states that David did not go up to heaven and that Psalm 110:1 refers to the exaltation of Jesus; but earlier it had been pointed out that David did not rise from the dead, his tomb still being present; if he did not rise, it is superfluous to say that he did not go up to heaven, unless resurrection and ascension are two aspects of the one act. David did not go up to heaven because he did not rise from the dead. Conversely, the Jesus who was raised is the Jesus who, as a necessary part of that resurrection, has been exalted to heaven. It is the resurrection/exaltation which makes Jesus both Lord and Christ, and if that is the case, then the risen Lord who appears to the disciples is already the exalted Lord, and Luke's ascension narratives, whatever else they may be, are not descriptions of the exaltation of Jesus.

\section{Exaltation in Luke-Acts apart from the ascension narratives}

Clearly the ascension narratives cannot be judged in isolation from those other passages in Luke-Acts which speak of resurrection - ascension - exaltation, and it is just these passages which prove an embarrassment for those like Lohfink who insist that luke, in contrast to the rest of the NT, always separates the resurrection and the ascension. For the fact is, as Lohfink himself

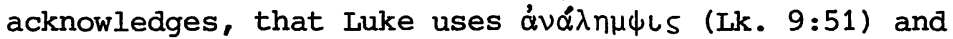

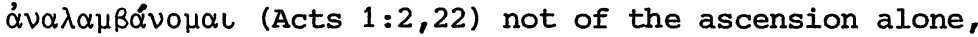
but of the whole complex of events including death, resurrection and ascension. In Acts 13:31ff. Luke emphasises the resurrection as opposed to the ascension (Lohfink thinks this is the result of a misunderstanding on Luke's part); and in Luke 24:26 the entry of Jesus into glory refers only to the resurrection. In fact, Lohfink's detailed study suggests that only Acts 5:30-32 and Acts 2:32-35 actually emphasise the difference between resurrection and exaltation, in the former by making the exaltation an event to be confirmed by witnesses and in the latter by using a different text of scripture to attest the exaltation from that which points to the resurrection. ${ }^{52}$ Not only can both of these passages be

52. Himmelfahrt 211-241. 
understood differently, ${ }^{53}$ but in the light of the majority of references one has to ask whether it is likely that they should be interpreted as Lohfink suggests. It is hard to resist the feeling that these texts are being squeezed into a predetermined mould of an ascension understood as exaltation, rather than allowing these texts to shape the interpretation of the ascension narratives; and that suspicion grows when, in respect of Luke 24:26, Lohfink writes: 'Have we here, therefore, an exaltation text in which the resurrection and exaltation of Jesus are thought of as a connected event - and on this occasion indeed by Luke? So at least many expositors feel. In the course of this investigation, however, we have had to confirm that Luke distinguishes most precisely between the resurrection and the exaltation of Jesus. 54 Is this not to stand exegesis on its head?

A similar lack of logic is surely present also in Franklin's treatment of this same theme. He speaks of 'other statements in Luke-Acts which link the glorification more closely to the resurrection'. Thus for him Luke 24:26 speaks of a glorification already accomplished at the resurrection (probably confirmed, he feels, by Ik. 22:69 and 23:42-43); the majority of speeches in Acts 'suggest no intermediate stage between resurrection and exaltation' (Acts $3: 15-16 ; 4: 10 ; 10: 40-43$ ); 'only in $2: 32-35$ are the two treated separately so that different functions are assigned to them'. But instead of drawing what would appear the necessary conclusion about Luke's understanding, having already determined that for luke the ascension is the glorification, Franklin concludes that 'All this points to the conclusion that luke's scheme is an artificial one' and demonstrates that 'Luke is not

53. See the brief discussion of Acts 2:32-35 above. The use of two texts surely does not have to mean that Luke was thinking of two separate events. That resurrection and ascension can be separated in thought, and different scriptures applied to each, does not necessarily involve their separation in reality. As far as Acts 5:30-32 is concerned, see F. F. Bruce, Commentary on the Book of the Acts (London: Marshall, Morgan \& Scott, 1965) 121-122; I. H. Marshall, The Acts of the Apostles (Leicester: IVP, 1980) 120; Franklin, Christ 33.

54. Himmelfahrt 236-237 (my translation). 
entirely consistent here'. 55 Who is being consistent and where is the artificiality? If not all, then the great majority of Luke's other references to

resurrection and exaltation show him to be at one with the rest of the NT, and while this cannot prove that the ascension accounts are not a direct contradiction of this model, it surely suggests a high degree of probability that these narratives also were seen by Luke to conform to it.

In the light of this brief discussion of the 'form' of the ascension narratives, the Christology of LukeActs, and the theology of exaltation found in these writings as a whole it can be argued with a fair degree of plausibility that the ascension narratives themselves, for all their uniqueness in the NT, do not have to be understood as exaltation narratives; on the contrary they can and should be seen as conforming to the resurrection/exaltation pattern of the rest of the NT in describing the final departure of the already exalted Lord.

\section{THE FORTY DAYS}

Even if it is not understood as an attempt to date the exaltation of Jesus, the reference to forty days in Acts 1:3 remains one of the most striking features of Luke's accounts. Not only does it raise the question of the relation between luke 24 and Acts 1, but it stands alone in the NT as an indication of the duration of the resurrection appearances. Unless it can be shown that luke has taken over this piece of chronology from the tradition, its inclusion by him would suggest that it has a particular significance for him. There are in fact a number of considerations which make it likely that this element in the narrative stems from Luke himself. The occurrence of the 'forty' in Acts 1:3, but not in vv. 9-12, where it would be quite fitting alongside the geographical information in the description of the ascension, points in this direction. Luke has provided clear dates for the resurrection and the coming of the Spirit, but as Menoud has observed, its absence from vv. 9-12 would suggest that Luke is not intending to date the ascension by means of this 'forty'.56 The absence

55. Christ 29-41; the quotations come from pp. 32,33 . 56. 'Pendant Quarante Jours' 152ff. 
of any reference to 'forty days' elsewhere in Acts, even where there was opportunity for it, as in Acts 10:41 and 13:31, points to a similar conclusion. ${ }^{57}$ While the

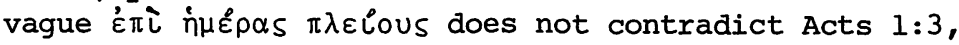
it would seem that exact chronology in respect of the ascension was not considered by luke to have been a part of early Christian proclamation, nor was it important in his own writing generally. Further, it is not only the rest of the NT which is silent in this respect; the number is absent from church tradition until the third century. Even Justin and Irenaeus, both of whom rely heavily on the Lukan writings for their accounts of the ascension, make no mention of the forty days, which would seem to indicate, as Lohfink observes, that 'they saw in this expression no tradition which ought to be furthered'.58 When it is also observed that Luke has a tendency to introduce numbers into his narratives in Acts, and that these are often both round numbers and numbers which have at least an undercurrent of theological significance, it becomes hard to resist the impression that the number forty in this connection derives from Luke. 59

57. This would also make improbable the suggestion that Luke learned of this figure only after he had completed the Gospel but before writing Acts. C. F. D. Moule ('The Ascension - Acts 1:9', Exp T 68 [1956-7] 205-209) suggests this, and that the discrepancy with the Gospel was the result of Luke's failure to revise his work. Even less likely is the comment of S. G. Wilson ('Ascension' $271 \mathrm{n} .13$ ) that 'we must allow for the possibility that by the time he came to write Acts Luke had quite simply forgotten what he wrote in Luke $24^{\prime}$.

58. Himmelfahrt 178.

59. Lohfink, for example, observes this principle in Luke's account of the growth of the church. At first there are 12; then there are 120 (10 x 12); then come the 3000 and 5000. No further numbers are given after this, partly because such numbers would lose their vividness, and partly because after 5000 in Greek

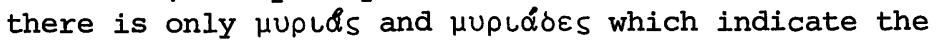
limits of counting (Himmelfahrt 178-179). 
What then was Luke's intention in introducing it? There are three possibilities:

(i) The number is meant to indicate an exact chronology. This is by no means impossible in the light of the prologue to the Gospel in which Luke sets out his purpose as to provide information as accurately as possible, and both Benoit and Moule feel that this time reference is perfectly plausible in view of the probable movement of the disciples at this period. 60 But without wishing to suggest that the number is wildly inaccurate, in the light of the observations above, other possibilities must be considered. 61

(ii) It is intended simply as a round number. It is commonly so used in the OT and NT to indicate a reasonable period of time, be it days or years. By its use in relation to events like the flood, the wilderness wandering and the giving of the Law, it came to be a number imbued with sacred significance. If Luke wished to find a number to express the duration of the resurrection appearances, and the particularly sacred nature of that period, then the most natural choice would be forty.

(iii) It has a speciflcally theological intention. Both F. Dornsieff and J. Manek, emphasising the OT background, point to incidents in the life of Moses. 62 Dornsieff refers to the forty days Moses spent on the mountain with God and compares it with the forty days which Jesus spent 'between two worlds'; but this hardly seems a real parallel. Moses was on the mountain to receive the Law from God and then to return to his people, whereas Jesus, on the contrary, is present with his people to give them instructions before he parts from them. Manek, who sees Jesus in Luke-Acts as the new Moses, compares the period of the wilderness wandering with the forty days of Acts 1; but, as Menoud

60. Benoit, 'Ascension' 241-242; C. F. D. Moule, 'The PostResurrection Appearances in the Light of Festival

Pilgrimages', NTS 4 (1957-8) 58-59. Cf. van

Stempvoort, 'Interpretation' 34.

61. Cf. the view of wilson that forty is not 'meant to be an exact number, though neither is it grossly inaccurate' ('Ascension' 270).

62. F. Dornsieff, 'Lukas der Schriftsteller' ZNW 35 (1936) 136; J. Manek, 'The New Exodus in the Books of Luke', Nov T 2 (1957) 8-23. 
tartly observes, the only thing in common to the two accounts is the number forty, and even this refers to years in the OT narrative and days in Acts 1.63 In fact, although there are a number of OT incidents which have contributed to the sacred nature of the number forty, thus forming a general background to Luke's use of the number, and although Luke's writings are rooted in the OT, ${ }^{64}$ it is unlikely that any one OT incident formed the basis for Luke's choice of this number. ${ }^{65}$

Menoud appeals to contemporary practice. By addressing only the Eleven, and not the larger group as in Luke 24, Luke shows that these witnesses are the authentic depositories of the teaching of the risen one, in that, just as it was the practice of Rabbis to repeat their teaching to their disciples forty times, so that it should be learned by heart, and thus could be transmitted whole and unaltered, so Jesus ensures that his disciples are adequately equipped to be his witnesses. It is Iuke's way of distinguishing between the specially instructed Eleven, whose speeches are reported in Acts, and other missionaries, like Barnabas and Philip, whose speeches are not reported because they were not part of this special group. It may well be correct that for luke much of the importance of this period lay in the instruction which Jesus gave, and the rabbinic practice to which Menoud refers is certainly suggestive (although whether it would have been grasped by Luke's readers must be doubtful). It is odd, however, that the incident which follows gives the very opposite impression, for the only glimpse afforded of the disciples themselves in v. 6 suggests that they had not learned the lessons they had been taught. Coming immediately before the ascension this hardly inspires confidence that the forty days' instruction has fulfilled its purpose in making these disciples the authentic

63. 'Pendant Quarante Jours' 150-151 n.2.

64. See J. Drury, Tradition and Design in Luke's Gospel (London: Darton, Longman \& Todd, 1976) 1-14.

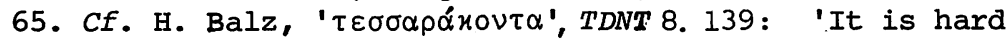
to find any specific O.T. type for it.' 
depositories of the Gospel. ${ }^{6}$ Equally it is by no means clear that Luke does differentiate between the Eleven and other witnesses. The only detailed reports of missionary preaching by members of this group are found in Peter's sermons, and one wonders why the rest of the Eleven are allowed to drop from sight, nothing of their preaching being reported; and why does luke give so much space to the speech of stephen, and devote the second half of Acts to Paul? Such considerations make Menoud's position difficult to maintain.

Lohfink connects the number forty with the fiftieth day, i.e. Pentecost. This Luke takes as his fixed point, which means that he then needs a number for the time of the appearances which is within the fifty days and which also fulfils certain conditions: it must be close to fifty, since the ascension and the coming of the spirit are closely related chronologically - cf.

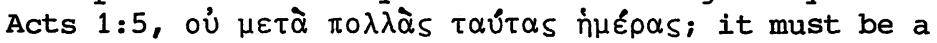
round number which no reader would understand as exact chronology, since luke does not intend to date the ascension; it must be a biblical number, since in texts of this sort Luke is at pains to write in the style of the LXX; and it must be a sacred number which is qualified for use on both Christological and salvationhistory grounds. The only number which fulfils all these conditions is forty, which is ideally suited to make the point luke has in mind - the sacred nature of the 'in-between' time. The number corresponds to Luke's use of Jerusalem as a geographical pointer, both geography and chronology being employed to join together the time of Jesus and the time of the church. The preparation of the apostles for their future role as witnesses involves convincing them of the reality of the resurrection and teaching them about the Kingdom of God so that there is continuity of teaching between Jesus and the church. ${ }^{67}$

66. Cf. Wilson's comment that 'if the disciples really retained the misunderstanding of $v$. $6 \mathrm{f}$. after 40 days (sic) teaching on the subject, then we would have to assume either that they were exceptionally stupid or that Jesus was a singularly incompetent teacher'

('Ascension' 277 n.39).

67. Himmelfahrt 184-186. 
It is possible that Lohfink has here uncovered the mechanics which lay behind the choice of forty, and in relating this to the theme of continuity he is, I think, on the right track. But is the continuity between Jesus and the church more than a continuity of teaching (especially as this emphasis on teaching must face many of the criticisms levelled at Menoud's similar position)? Is the forty days simply a theological device to bridge a difficult gap between otherwise watertight compartments in Luke's scheme of salvationhistory? Or is luke pointing to an actual continuation of the ministry of Jesus which, through the resurrection and exaltation, has now entered upon a new phase, and the number forty is one of several indications in Acts 1 in particular and Acts in general of such a continuing ministry? ${ }^{68}$ Luke uses the expression 'forty days' on only one other occasion in Luke-Acts, to denote the period of the temptation in the wilderness (Lk. 4:2). E. Preusschen boldly states that 'the forty days are thought of as an introduction to the work of the exalted Christ just as the forty days' fast was an introduction to the earthly work', and M. Goguel was of the opinion that there was a sense in which Jesus needed to be prepared for his heavenly ministry just as he had prepared for his earthly ministry. 69 Were such a parallel an isolated phenomenon its significance would be greatly reduced, but it should be seen as part of a much wider series of parallels which, as G. W. H. Lampe notes, occur in Luke's writings in such a way as to link the life and work of Jesus with the story and mission of the church. ${ }^{70}$ The most thoroughgoing attempt to

68. I am developing this theme of a continuing ministry of Jesus in Acts elsewhere. The implication of Acts 1:1 must be taken seriously. In this connection mention should be made of R. F. O'Toole, The Unity of Luke's Theology (Wilmington: Glazier, 1984).

69. E. Preusschen, Die Apostelgeschichte (Tübingen: Mohr, 1912); M. Goguel, La foi à la résurrection de Jésus dans la christianisme primitif (Paris: 1933) 354.

70. G. W. H. Lampe, 'The Holy Spirit in the Writings of St. Luke' in D. E. Nineham (ed.), Studies in the Gospels (Oxford: OUP, 1955) 159-200, esp. $194 \mathrm{ff}$. Lampe, in fact, does not place the forty days of Acts into this Lukan parallelism, presumably because he sees the baptism of Jesus as corresponding to the Spirit-baptism at Pentecost. 
interpret the writings of luke in this way has been made by by M. D. Goulder. ${ }^{71}$ The extreme form of typological interpretation proposed by Goulder must be reckoned unlikely, but the number of apparent parallels between the the Gospel and Acts is impressive, and it is not necessary to demonstrate that they are part of a deliberately typological presentation to maintain that they are intentional. The effect of these parallels upon the reader is frequently to remind $\mathrm{him}$ as he reads Acts of the ministry of Jesus as recounted in the Gospel. As such they are a literary device which constantly suggests the continued presence and activity of the risen Lord. That the forty days of Acts 1:3 is part of such a presentation is suggested by the way in which Luke 24 and Acts 1 appear deliberately to recall the beginning of the Gospel: in Luke 24:50-53 note should be taken of the priestly motif which recalls the incomplete service rendered by Zechariah (possibly also the blessing pronounced by Simeon), the temple with which the Gospel ends played an important part in the beginning, and the themes of joy and worship are also very much to the fore in the infancy narratives; ${ }^{72}$ in Acts 1 mention should be made of the choosing of the apostles, the teaching about the kingdom of God, the reference to the ministry of John the Baptist, and, of course, the forty days. What Luke is describing is a new beginning, yet a beginning which recalls the beginning already made in the Gospel and with which the story of Acts is continuous. The forty days, therefore, is a vital vehicle for conveying Luke's theology of continuity, and as such this leads us into the final section of this study.

\section{THE SIGNIFICANCE OF THE ASCENSION NARRATIVES IN LUKE-ACTS}

However the ascension narratives are understood, it must be clear that their presence in Luke-Acts means that they play an important part in Luke's thinking and thus contribute in a crucial way to the message he wishes to convey. That the two accounts differ to some extent in the theological message they convey, as is shown by the

71. M. D. Goulder, Type and History in Acts (London: SPCK, 1964); The Evangelists' Calendar (London: SPCK, 1978).

72. Cf. J. Ernst, Das Evangelium nach Lukas (Regensburg: Pustet, 1977) 672-673. 
different motifs present in the two narratives, is true, but these differences should not be over-emphasised. The one event of the ascension holds the Gospel and Acts together, yet the luke 24 account is peculiarly appropriate for the climax of a Gospel just as the Acts account is fitting for the commencement of that story; but many of the same elements and ideas are present in both narratives which are intended to complement rather than contradict one another. ${ }^{73}$ No more than a brief summary is attempted here of the main features of Luke's presentation.

(i) The Ascension is the confirmation of the exaltation of Christ and his present Lordship. If, as was argued above, the ascension narratives do not describe the exaltation of Jesus, the presence of the exaltation motifs must be accounted for. Again it must be stressed that the forty days of the appearances is for the benefit of the disciples so that the necessarily invisible event of the resurrection can be demonstrated beyond any doubt by means of the appearances, the reality and corporeal nature of which luke emphasises more than any other NT writer. In the same way the disciples and, of course, Luke's readers, must be convinced of the equally invisible exaltation of Jesus and his present reign at the right hand of the Father, and it is this which is dramatically confirmed in the vivid ascension narratives. ${ }^{74}$ As at the transfiguration the cloud of the divine presence and glory makes it clear where Jesus belongs, and his parting from the disciples into the cloud which hides him from their sight as well as bears him up confirms his exalted position; the fourfold repetition of the phrase 'into heaven' in Acts $1: 10-11$ is as clear an indication as there could be of the reality of Christ's Lordship (note also the same phrase in the longer reading of luke 24:51); and as if this were not sufficient, what they have seen is confirmed by what they

73. See especially van Stempvoort, 'Interpretation' 42 .

74. Franklin (Christ 39) is quite correct, therefore, to say that 'The description of the actual event is given only as it bears upon the disciples; it is seen in terms of its significance for them'; but this is hardly 'a complete contrast with luke 24:50-1'. It is more a difference of emphasis, the luke 24 presentation being more fitting for the climax of the Gospel. 
hear from the angelic messengers. While therefore it is necessary to reject Franklin's understanding of the ascension as the moment of glorification, we heartily concur with his statement that 'the ascension is the visible and concrete expression of Jesus' status'.75 The Lordship of Jesus presented through the ascension narratives makes not only a fitting climax to the Gospel, but a necessary one, for it is that Lordship which gives meaning to the whole Gospel, indeed provides the vantage point from which it can be understood in its full significance; similarly the story of the church is only rightly perceived in the light of the exaltation of the crucified Jesus who even now reigns with the Father, and thus Acts 1 makes it clear that this second volume is not to be simply 'church history' but a further proclamation of the Gospel of the exalted Christ.

(ii) The ascension is the explanation of the continuity between the ministry of Jesus and that of the church. It is often said that the ascension accounts mark an ending and a beginning. It might be more accurate to say that they present the point of transition at which the story which has begun in the earthly ministry of Jesus in one mode becomes the same story continuing in a different mode. It is this note of continuity which is central. ${ }^{76}$ The ascension must be understood in the light of the implication contained in Acts 1:1, that as the Gospel recounted what Jesus began to do and to teach, so Acts will recount what he continues to do and to teach. ${ }^{77}$ In this context it is also important to observe that for Luke this 'going away' of Jesus at the ascension does not lead to an

75. Christ 30 .

76. Wilson comments: 'Thus while it marks a division between the story of Jesus and the history of the Church, much more significant is the way in which it firmly links these two epochs' ('Ascension' 276). 'As his double account of the Ascension and his concept of Apostleship show, Luke was far more concerned to show how these two epochs were linked than how they were separated' ('Ascension' 276 n.35).

77. That this is how Acts $1: 1$ should be interpreted is argued in the thesis on which I am presently working, entitled 'The Ministry of the Exalted Christ in LukeActs: An Aspect of Lukan Continuity' . Cf. A. Hilgenfeld, 'Lucas und die Apostelgeschichte', ZWTh 50 (1907) 182; Preusschen, Apostelgeschichte 4; Bruce, Acts 32; Goulder, Type 63-64. 
absentee Christ, as is frequently asserted; ${ }^{78}$ rather, and this helps to explain the joy of the disciples in Luke 24, as H. Schlier puts it so well, Luke 'will show that the parting is more than a farewell, indeed basically not a farewell at all, but the withdrawal to a greater nearness'. ${ }^{79}$

(iii) The Ascension is the culmination of the resurrection appearances. Precisely because Luke has emphasised the corporeality of the resurrection appearances it was necessary that he should emphatically declare that such appearances, and such a presence of the risen Lord, could not be considered in any way the norm of Christian experience. Hence the air of finality that pervades both ascension accounts. Luke understood the importance of this for the disciples themselves, who had spent the years of the ministry in the presence of the earthly Jesus, and had, uniquely, been the recipients of regular appearances of the risen Lord. As Moule comments, 'The decisive cessation of the appearances in one final appearance.... was clearly something needed by the friends of Jesus who had known him so closely as an earthly friend and intimate that for them the problem was how to be weaned of this audio-visual, quasi-physical relationship'.80 Luke himself, however, had never seen the risen Christ in this way nor had any of his readers, and thus Luke makes it clear that such appearances are not promised to everyone; indeed once the reality of the resurrection has been established they must end. ${ }^{81}$ The

78. As by Moule, 'Christology' 180; J. D. G. Dunn, Unity and Diversity in the New Testament (London: SCM, 1977) 224-225. Nowhere is this suggestion put more forcefully than by J. A. Ziesler, 'Matthew and the Presence of Jesus', Epworth Review 11 (1984) 55:

'Luke clearly gets Jesus off the stage at the end of the Gospel (Luke 24:51) and again at the beginning of Acts (Acts 1:2, 9-11) and with almost entire consistency keeps him off.'

79. H. Schlier, 'Jesu Himmelfahrt nach den Lukanischen Schriften' in his Besinnung auf das neue Testament (Freiburg: Herder, 1964) 231.

80. C. F. D. Moule, The Significance of the Message of the Resurrection for Faith in Jesus Christ (London: SCM, 1968) 5.

81. Cf. A. Schlatter, Das Evangelium des Lukas (Stuttgart: Calwer, 1960) 457. 
visible presence of Christ is not necessary for faith. In his ascension accounts luke is depicting what is presupposed in 1 Corinthians 15:5-7, that the appearances came to an end, and so he presents 'an acted declaration of finality'.

(iv) The Ascension is the prelude to the sending of the spirit. Here, as in (iii) above, Lukan theology comes very close to that of the Fourth Gospel, in which the evangelist points out that the Spirit was not yet (given) because Jesus had not been glorified, and that unless Jesus went away the Spirit would not come, but that in the coming of the Spirit Jesus would return to his people. So for Luke also, 'being therefore exalted at the right hand of God, and having received from the Father the promised Holy Spirit, he has poured out this which you see and hear' (Acts 2:33); and by means of the Joel quotation earlier in Peter's sermon it is made clear that it is the exaltation of Jesus which marks the arrival of the last days in which the Spirit is poured out in abundance. Both Luke 24 and Acts 1 make quite clear the connection between the departure of Jesus and the coming of the spirit.

(v) The Ascension is the foundation of Christian mission. In both Luke 24 and Acts 1 the spirit is promised, and the ascension takes place, firmly within a context of mission. The spirit is promised as the power for mission by the Lord whose exaltation is the very foundation and raison d'être of mission. This too has affinities with John 20 and is reminiscent of Matthew 28:18-20.

(vi) The Ascension is the pledge of the return of Christ. For luke the ascension is not just the confirmation of a present reality but also the certain pledge of a future consummation - 'This Jesus, who was taken up from you into heaven, will come in the same way as you saw him go into heaven' (Acts 1:11; cf. 3:20-21). To say, as U. Wilckens does, that 'Christ's ascension on a cloud has no other significance than to bring Jesus to the place from which he will return at the end' is a considerable overstatement; but it rightly emphasises the connection between these two events. ${ }^{83}$ And luke does this

82. Moule, 'Ascension' 208.

83. U. Wilckens, Resurrection (Edinburgh: St. Andrew, 1977) 69-70. 
not to defer indefinitely the Parousia but to make its certainty a constant reality in the life of God's people.

To conclude. Rightly understood, the ascension narratives of Luke are perfectly in keeping with the exaltation kerygma of the rest of the NT and make a vital theological contribution to NT teaching, and provide a crucial key to the unlocking of Luke's theology and purpose. 